MARCOS ORESTE COLPO

\title{
IDÉIAS PARA UMA PEDAGOGIA DA DESCONSTRUÇÃO: DESDOBRAMENTOS DA ONTOLOGIA DE MARTIN
} HEIDEGGER

Doutorado em Filosofia da Educação

$$
\text { USP - SÃO PAULO }
$$




\section{IDÉIAS PARA UMA PEDAGOGIA DA DESCONSTRUÇÃO: DESDOBRAMENTOS DA ONTOLOGIA DE MARTIN HEIDEGGER}

Tese apresentada como exigência parcial para obtenção do grau de doutor em Filosofia da Educação à Comissão Julgadora da Universidade de São Paulo, sob a orientação da Profa. Dra. Maria Nazaré de Camargo Pacheco Amaral.

$$
\text { USP - SÃO PAULO }
$$


Comissão julgadora: 


\section{Agradecimentos}

Gostaria de agradecer a minha orientadora Profa. Dra. Maria Nazaré de Camargo Pacheco Amaral, pelo acolhimento e pela confiança e liberdade com que acompanhou meu percurso como pós-graduando da FEUSP, desde o mestrado e agora no doutorado.

Gostaria de agradecer aos professores que participaram da banca de Exame de Qualificação, pelas contribuições oferecidas ao meu trabalho, iluminando pontos que estavam obscuros, fruto da observação cuidadosa, responsável e rigorosa para melhor compor o tema dessa tese.

Gostaria de agradecer a Olga minha mulher pelo incentivo e apoio nas minhas apreensões, gestando condições para que eu pudesse realizar este trabalho. Aos meus filhos Igor, Gustavo e Natalia que mesmo sem saber bem do que se tratava, respeitaram minha solidão e meu empenho diante do computador.

Gostaria de agradecer aos meus amigos da Associação Brasileira de Daseinsanalyse, companheiros que desde 1974, cuidam para que a Daseinsanalyse, tenha o vigor e a inserção devida no âmbito das práticas clínicas e quem sabe agora também na educação.

Gostaria de agradecer a acolhida que a FEUSP teve para comigo em todo este percurso, tanto do corpo docente como da secretaria do pós-graduação que sempre foi muito eficiente e simpática. 


\section{RESUMO}

A presente tese tem por finalidade propor algumas idéias que possam sustentar o que denominamos "Pedagogia de Desconstrução", idéias estas desdobradas com base na ontologia fundamental de Martin Heidegger, publicada em 1927 (Ser e tempo) e das publicações realizadas a partir de 1930, que marcaram a virada (die Kehre) do seu pensamento.

O sentido da palavra desconstrução (Ab-Bau) ou destruição (Detruktion) em Heidegger está associado à identificação de um modo de pensar característico do ocidente, denominado pensamento metafísico, que se estabeleceu a partir de Platão. Tal modo de pensar consolida-se por meio de uma interpretação objetivada do ser dos entes (Vorhandenheit), cujos desdobramentos fizeram com que a metafísica esquecesse o fenômeno do mundo, permanecendo presa ao modelo do ver teorético. O sentido da desconstrução alinha-se com a tentativa de recuperar a diferença ontológica entre ser e ente, portanto, desconstruir o modo objetivado de alocar o ser dos entes, meditar sobre o sentido do ser e re-visitar (An-denken) o pensamento metafísico, desvelando aquilo que não foi pensado pela educação a partir destas determinações metafísicas.

O modo de pensar metafísico chega à plenitude de suas possibilidades em nossa época atual, séculos 20 e 21, exercida por dois fenômenos que são: a ciência e a técnica moderna, que vem impor um modo de ser e pensar sobre cujas conseqüências Heidegger procurou nos alertar quanto às suas conseqüências nas significativas conferências realizadas após 1930. Tal modo de pensar, instrumentado pela eficiência da técnica e da logística dos mercados, nos enreda numa pseudoproximidade com as coisas e com os outros, entre outros sintomas que nos fazem adentrar numa noite escura e densa, obscurecendo-nos o mundo. Podemos testemunhar este mundo obscurecido por meio de alguns sintomas de nossa época atual, como a massificação dos homens, da fuga dos deuses, a devastação da terra, a aniquilação da coisa, bem como pela técnica moderna cuja essência consolida-se como uma contenda, uma provocação do homem em relação à natureza.

É diante destes alertas demonstrados por Heidegger e testemunhados por nós que pensamos em propor algumas idéias que possam orientar uma 
pedagogia, preocupada em exercer alguns contrapontos aos imperativos de nossa época atual. Conscientes dos limites deste projeto em consonância com os entendimentos de Heidegger sobre os limites de nosso empenho em relação à metafísica, estamos propondo algumas pequenas saídas que se consolidam na tentativa de resgatar o vigor de um pensar que se realiza na unidade entre ser e pensar, de "conduzir" (ex-ducere) o ser-aí em direção ao conhecimento de si mesmo e de voltar-se para uma relação com o real pautada pela poiésis, ou seja, por uma linguagem e por um fazer que envolve levar à luz o que se apresenta realizado pela essência da verdade, compreendida como sendo a liberdade de deixar ser 0 ente.

É neste âmbito da poiésis que o pensamento e os afazeres dos homens podem desconstruir o modo de desvelar o ser dos entes, dominado por um pensamento cuja armação (Gestell) submete as coisas à tríade: exploração, produção e consumo. $\mathrm{O}$ âmbito da poiésis em Heidegger inspira-se no poeta Hölderlin e com ele gesta-se a possibilidade de um outro modo de relação com o real, cujos modelos ônticos exercem um contraponto à armação, modelos estes inscritos no que Heidegger denomina por quadrindade, constituída pelo espelhamento entre os diferentes envios do ser: a terra; e o céu; os divinos e os mortais. 


\section{SUMMARY}

The aim of this thesis is to propose some ideas supporting what we refer to as "Deconstruction Teaching", arising from Martin Heidegger's 1927 work on basic ontology (Being and Time) and other publications as of 1930, marking the turning point (die Kehre) in his thinking.

For Heidegger, the meaning of the term deconstruction $(A b-B a u)$ or destruction (Detruktion) is associated with a characteristic Western manner of thinking, known as metaphysical thinking, a concept originally identified by Plato. This manner of thinking is reinforced through the objective interpretation of the being of being (Vorhandenheit), an approach whereby metaphysics ignores the world phenomenon, and remaines mired in the theoretical view model. The meaning of deconstruction becomes aligned with the attempt to recover the ontological difference between being and the being and, thus, deconstructs the objective interpretation of allocating the being of the beings, to meditate on the meaning of the being and revisiting (An-denken) metaphysical thought, in order to reveal that which was not considered by education based on these metaphysical conclusions.

The manner of metaphysical thinking reached the peak of its capacity in our own times, the twentieth and twenty-first centuries. It was exercised by two phenomena, science and modern techniques, which themselves imposed a way of being and of thinking of whose consequences Heidegger strove to warn us in key talks given after 1930. This way of thinking, led by the efficient techniques and logistics of the markets, binds us into pseudo-proximity with things and with others, among other symptoms that thrust us into a dark and dense night, blinding us to the world. We can witness this obscured world through some of the symptoms of our time. Examples are the reduction of humans to their lowest common denominator, the exodus of the gods, the devastation of the earth, the annihilation of the thing, in addition to modern techniques, whose essence has hardened into dispute, man provoking nature.

It is thanks to Heidegger's warnings which we ourselves have also witnessed, that we decided to present some ideas that could steer teaching, in its anxiety to place some counterpoints to today's imperatives. We are aware of the 
limits of this project in accordance with Heidegger's views on the limits of our performance in relation to metaphysics, and propose some minor solutions that arose in the attempt to redeem the vigor of a thinking process developed in the space between to be and to think, of "leading forth" (ex-ducere) being in the direction of self-knowledge and to return to a relationship with what is real, based on poiesis. In other words, through a language and through action involving bringing to light what is realized by the essence of truth, understood as being the freedom to cease being the being.

It is in this very environment of poiesis that man's thoughts and actions can deconstruct the manner of revealing the being of the beings, dominated by a thought whose configuration (Gestel) submits such things to that trinity of exploration, production, and consumption. The environment of poesis in Heidegger was inspired by the poet Hölderlin and it is with him that the possibility of another relationship with reality is born, one whose ontological models exercise a counterpoint to this configuration. These models are part of what Heidegger defines as the "quadrinity", formed by the reflection of three different aspects of the being: earth, heaven, the gods, and mortals. 